\title{
Rancangan D-Optimal Model Gompertz dengan Maple
}

\author{
Tatik Widiharih ${ }^{1}$, Budi Warsito ${ }^{2}$ \\ ${ }^{1,2}$ Departemen Statistika Universitas Diponegoro. \\ e-mail: wiwied t@@undip.ac.id ; widiharih@gmail.com
}

DOI: 10.14710/medstat.10.1.1-12

\section{Article Info:}

Received: 2 Maret 2017

Accepted: 14 Juni 2017

Available Online: 14 Agustus 2017

Keywords:

D-optimal, Generalized Equivalence

Theorem, Tchebysheff System,

Minimally Supported, Uniform

Weight.

\begin{abstract}
Gompertz model is used in many areas including biological growth studies, animal and husbandry, chemistry, and agricultural. Locally Doptimal designs for Gompertz models with three parameters is investigated. We used the Generalized Equivalence Theorem of Kiefer and Wolvowitz to determine D-optimality criteria. Tchebysheff system is used to decide that the D-optimal design is minimally supported design or nonminimally supported design. The result, D-optimal design for Gompertz model is minimally supported design with uniform weight on its support.
\end{abstract}

\section{PENDAHULUAN}

Model nonlinear banyak digunakan untuk menggambarkan kurva pertumbuhan. Model-model tersebut bisa berupa model eksponensial, sigmoidal atau kurva berbentuk S. Model Gompertz bisa digunakan sebagai kurva pertumbuhan dengan kurva berbentuk huruf S. Pada awalnya model Gompertz digunakan pada bidang pertanian dan peternakan. Dalam perkembangannya model Gompertz dapat digunakan pada model uji data hidup (life time test). Fungsi Gompertz dengan tiga parameter mempunyai bentuk sebagai berikut:

$$
y=\theta_{3} \exp \left(-e^{-\theta_{1} x+\theta_{2}}\right), x \in[0, b]
$$

Model fungsi Gompertz dengan tiga parameter seperti Persamaan (1) mempunyai kurva berbentuk huruf S. Kurva dari model Persamaan (1) untuk $\theta_{3}=0,5$ dan $\theta_{2}=1$ pada beberapa nilai $\theta_{1}$ disajikan pada Gambar (1) .

Masalah utama yang sering muncul dalam merancang suatu percobaan adalah bagaimana menentukan titik-titik rancangan yang harus dicobakan sehingga memenuhi kriteria optimal yang telah ditetapkan. Kriteria D-optimal adalah kriteria keoptimalan dengan tujuan meminimumkan variansi dari penduga parameter, sehingga diharapkan parameter dalam model akan signifikan (hipotesis yang menyatakan bahwa nilai parameter sama dengan nol ditolak). Rancangan optimal digunakan untuk menentukan titik-titik rancangan beserta proporsi (ulangan) yang harus dicobakan sehingga terpenuhi kriteria optimal yang telah ditetapkan. Rancangan optimal ini hanya berlaku untuk model hubungan fungsional dari peubah faktor dan peubah respon yang telah ditetapkan. 
Secara umum rancangan optimal dapat diterapkan pada perancangan percobaan dan analisis regresi. Wald (1943) mengenalkan suatu kriteria optimal yang penekanannya pada kualitas estimator dari parameternya. Selanjutnya Kiefer and Wolfowitz (1959) menamakan kriteria yang diperkenalkan oleh Wald ini dengan nama kriteria D-optimal.

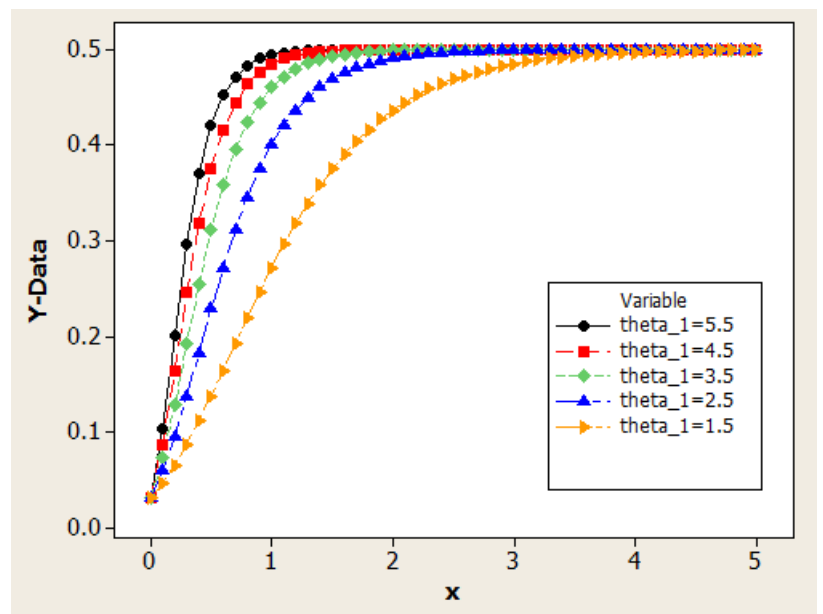

Gambar 1. Kurva Fungsi Gompertz Tiga Parameter dengan $\theta_{3}=0,5$ dan $\theta_{2}=1$ pada Beberapa Nilai $\theta_{1}$

Kriteria D-optimal ini juga dikenal dengan kriteria determinan. Kriteria D-optimal diperoleh dengan memaksimumkan determinan dari matriks informasi Fisher. Chernoff (1953) menentukan keoptimalan dari regresi linear sederhana pada kasus variansi error konstan. Chernoff menyatakan bahwa rancangan optimal lokal diperoleh dengan cara memberikan dugaan terhadap nilai parameternya kemudian memaksimumkan kriteria optimal berdasarkan dugaan nilai parameter yang diberikan. Selanjutnya rancangan optimal untuk model regresi berkembang setelah Kiefer and Wolfowitz (1960) menemukan Teorema Equivalensi Tergenaralisasi (Generalized Equivalence Theorem), yang dipertegas oleh Kiefer (1961) dan Kiefer (1974). Selanjutnya White (1973) menjeneralisasi Teorema Equivalensi Tergenaralisasi untuk model nonlinear. Penentuan rancangan D-optimal untuk model nonlinear relatif lebih sulit dibandingkan dengan model linier, hal ini disebabkan karena elemen-elemen matriks informasi mengandung parameter yang tidak diketahui nilainya. Untuk mengatasi hal ini, peneliti seharusnya mempunyai informasi awal tentang nilai parameter model, sehingga rancangan D-optimal lokal dapat diperoleh.

Pada awalnya rancangan D-optimal digunakan pada model linier, khususnya model regresi polinomial. Pada kasus homoskedastik telah diteliti (Fang (2002), Luoma, et al. (2007), Boon (2007) dan Atkinson, et al. (2007)). Sedangkan pada kasus heteroskedastik penentuan rancangan D-optimal dengan menggunakan funsi bobot. Beberapa peneliti telah melakukan dengan menggunakan fungsi bobot yang berbeda-beda (Fang (2003), Huang, et al. (1995), Antille, et al. (2003), Dette and Trampish (2010)). Widiharih, et al. (2013a), menggunakan tiga macam fungsi bobot dan diaplikasikan pada regresi polinomial derajad tiga.

Rancangan D-optimal model Eksponensial juga telah diteliti baik pada kasus homoskedastik maupun heteroskedastik. Pada kasus homoskedastik telah diteliti oleh Imhoff (2001), Hans and Chaloner (2003), Dette, et al. (2006), Dette and pepelyshev 
(2008), dan Widiharih, et al. (2013b, 2014, 2016b). Li and Majumdar (2008) menemukan teorema yang digunakan untuk memutuskan apakah rancangan minimal (minimally supported desin) yaitu banyaknya titik rancangan sama dengan banyaknya parameter dengan ulangan sama dapat digunakan. Dalam makalah ini penulis mengadopsi Teorema (1) dari Li and Majumdar (2008). Beberapa rancangan D-optimal untuk model kurva pertumbuhan juga telah diteliti, diantaranya Chang and Lay (2002), Li and Balakrishnan (2011). Rancangan D-optimal untuk model dengan kurva berbentuk huruf S telah diteliti, khususnya model Michaelis Menten dan Emax (Widiharih, et al. (2015)), dan model Morgan Mercer Flodin dengan tiga parameter (Widiharih, et al. (2016a)).

Pada makalah ini dibahas rancangan D-optimal model Gompertz dengan tiga parameter sebagai berikut:

$$
y=\theta_{3} \exp \left(-e^{-\theta_{1} x+\theta_{2}}\right)+\varepsilon, \quad x \in[0, b]
$$

dengan $\varepsilon$ diasumsikan berdistribusi normal, independen dengan rata-rata nol dan variansi konstan. Penulis menggunakan Teorema Equivalensi Tergeneralisasi Kiefer Wolfowitz (1960) dan Teorema 1 bagian 3 dari Li and Majumdar (2008). Konsep sistem Tchebysheff diperlukan untuk menentukan banyaknya akar dari fungsi variansi terstandar. Berdasarkan banyaknya akar dari fungsi variansi terstandar dan menggunakan Teorema 1 bagian 3 dari $\mathrm{Li}$ and Majumdar (2008) dapat diputuskan apakah rancangan minimal bisa digunakan.

\section{DISKRIPSI TEORITIS}

Model nonlinear yang digunakan dengan bentuk :

$$
y=\eta(x, \theta)+\varepsilon
$$

dengan asumsi $\varepsilon$ independen berdistribusi Normal dengan rata-rata 0 dan variansi konstan. Rancangan dengan $p$ titik rancangan dinotasikan dengan :

$$
\xi=\left(\begin{array}{llll}
x_{1} & x_{2} & \cdots & x_{p} \\
w_{1} & w_{2} & \cdots & w_{p}
\end{array}\right)
$$

$$
\begin{aligned}
\text { dengan }: & w_{i}=\frac{r_{i}}{n} \\
& r_{i}: \text { banyaknya ulangan untuk titik rancangan } x_{i} \\
& n: \text { banyaknya pengamatan dan } n=\sum_{i=1}^{p} r_{i} \\
& \sum_{i=1}^{p} w_{i}=1
\end{aligned}
$$

Rancangan $\xi$ seperti pada Persamaan (4), $x_{i}, i=1,2, \ldots, p$ merupakan titik-titik rancangan dan $w_{i}, i=1,2, \ldots, p$ merupakan proporsi untuk $x_{i}$ yang bersesuaian. Menentukan banyaknya titik rancangan ( $p$ ) sangat sulit, dengan menggunakan konsep sistem Tchebysheff dapat ditentukan apakah dapat digunakan rancangan minimal (minimally supported design) yaitu banyaknya titik rancangan sama dengan banyaknya parameter dalam model dengan proporsi sama.

Matriks informasi dari rancangan (4) adalah :

$$
\boldsymbol{M}(\xi, \boldsymbol{\theta})=\sum_{i=1}^{d} w_{i} \boldsymbol{h}(\boldsymbol{x}) \boldsymbol{h}^{T}(\boldsymbol{x})
$$


merupakan matriks simetri berukuran $k x k$ dengan $k$ adalah banyaknya parameter dalam model, dengan : $\boldsymbol{h}(\boldsymbol{x})=\left(\frac{\partial \boldsymbol{\eta}(\boldsymbol{x}, \boldsymbol{\theta})}{\partial \theta_{1}}, \frac{\partial \boldsymbol{\eta}(\boldsymbol{x}, \boldsymbol{\theta})}{\partial \theta_{2}}, \ldots, \frac{\partial \boldsymbol{\eta}(\boldsymbol{x}, \boldsymbol{\theta})}{\partial \theta_{k}}\right)^{T}$. Matriks informasi pada Persamaan (5) masih mengandung parameter. Dalam melakukan percobaan, peneliti sebaiknya telah mempunyai informasi tentang nilai parameter, sehingga bila nilai parameter dimasukkan pada Persamaan (5), determinan dari matriks informasi merupakan fungsi dengan peubah dalam $x=\left(x_{1}, x_{2}, \ldots, x_{p}\right)$. Fungsi dispersi (variansi terstandar) yang bersesuaian dengan rancangan $\xi$ adalah :

$$
\mathrm{d}(x, \xi)=\boldsymbol{h}^{T}(\boldsymbol{x}) \mathbf{M}^{-1}(\xi) \mathbf{h}(\boldsymbol{x})
$$

Nilai dari variansi terstandar untuk rancangan D-optimal antara nol sampai dengan $k$ ( $k$ : banyaknya parameter dalam model) dan maksimum dari variansi terstandar terjadi pada titik-titik rancangan. Berikut definisi dari rancangan dengan kriteria D-optimal.

Definisi 2.1. [Atkinson et al (2007)]

Kriteria D-optimal adalah kriteria yang diperoleh dengan cara meminimumkan $\Psi\{\boldsymbol{M}(\xi)\}$ dengan: $\Psi\{\boldsymbol{M}(\xi)\}=\log \left|\boldsymbol{M}^{-1}(\xi)\right|=-\log |\boldsymbol{M}(\xi)|$

Berdasarkan Definisi 2.1, kriteria D-optimal diperoleh dengan cara memaksimalkan | $(\boldsymbol{M}(\xi)) \mid$. Untuk menunjukkan bahwa rancangan $\xi$ seperti pada Persamaan (4) memenuhi kriteria D-optimal digunakan Teorema Equivalensi Tergeneralisasi dari Kiefer and Wolfowitz (1960) berikut.

Teorema 2.1, Teorema Equivalensi Tergeneralisasi Kiefer and Wolfowitz (1960)

Tiga kondisi berikut adalah equivalen ;

1. Rancangan $\xi^{*}$ memaksimalkan $|M(\xi)|$

2. Rancangan $\xi^{*}$ meminimumkan $\max _{x} d(x, \xi)$

3. $\max _{x} d(x, \xi)=k$, dengan $k$ adalah banyaknya parameter dalam model.

Secara ringkas Teorema Equivalensi Tergeneral dapat dinyakan sebagi berikut :

$$
\text { Rancangan } \boldsymbol{\xi}^{*} \text { memaksimalkan }|M(\xi)| \Leftrightarrow \mathrm{d}(x, \xi)=\boldsymbol{h}^{\boldsymbol{T}}(\boldsymbol{x}) \boldsymbol{M}^{-\mathbf{1}}(\boldsymbol{\xi}) \boldsymbol{h}(\boldsymbol{x}) \leq \mathrm{k}
$$

Untuk menunjukkan bahwa rancangan $\xi$ seperti pada Persamaan (4) merupakan rancangan D-optimal dengan melakukan cheking bahwa terpenuhinya :

$$
\mathrm{d}(x, \xi)=\boldsymbol{h}^{T}(\boldsymbol{x}) \boldsymbol{M}^{-1}(\xi) \boldsymbol{h}(\boldsymbol{x}) \leq \mathrm{k}
$$

Konsep sistem Tchebysheff diperlukan untuk mengetahui tingkah laku dari variansi terstandar $\mathrm{d}(x, \xi)$. Prinsip yang dipentingkan adalah banyaknya akar-akar dari $\mathrm{d}(x, \xi)-$ $k+$ c: $0<c<\varepsilon$, dengan $k$ banyaknya parameter dalam model. 
Definisi 2. 2. [Karlin and Studden (1966)]

Suatu himpunan fungsi $\Theta=\left\{u_{0}, u_{1}, \ldots, u_{n}\right\}$ dari $C(K)$ adalah suatu sistem Tchebysheff (disingkat sistem T) jika setiap polinomial: $p=a_{0} u_{0}+a_{1} u_{1}+\ldots+$ $a_{n} u_{n}$ dengan tidak semua koefisien sama dengan nol, dan mempunyai paling banyak $n$ akar yang berbeda dalam $K$.

Cara lain untuk menunjukkan bahwa $\Theta=\left\{\mathrm{u}_{0}, \mathrm{u}_{1}, \ldots, \mathrm{u}_{\mathrm{n}}\right\}$ merupakan sistem Tchebysheff dengan menggunakan Lemma berikut:

Lemma 2.1. [Shadrin (2005)]

Kondisi berikut ekuivalen:

1. $\left\{u_{i}\right\}_{i=0}^{n}$ suatu sistem Tchebysheff.

2. Untuk sembarang $n+1$ titik yang berbeda $\left\{x_{i}\right\}_{i=0}^{n} \in K$, determinan berikut tidak nol,

$$
D\left(\begin{array}{cccc}
u_{0} & u_{1} & \ldots & u_{n} \\
x_{0} & x_{1} & \ldots & x_{n}
\end{array}\right)=\left|\begin{array}{ccc}
u_{0}\left(x_{0}\right) & \ldots & u_{n}\left(x_{0}\right) \\
\ldots & \ldots & \ldots \\
u_{0}\left(x_{n}\right) & \ldots & u_{n}\left(x_{n}\right)
\end{array}\right|
$$

3. Jika $\left\{x_{i}\right\}_{i=0}^{n}$ titik-titik yang berbeda dari $K$ dan $\left\{y_{i}\right\}_{i=0}^{n}$ sembarang bilangan, maka masalah interpolasi

$a_{0} u_{0}\left(x_{i}\right)+a_{1} u_{1}\left(x_{i}\right)+\ldots+a_{n} u_{n}\left(x_{i}\right)=y_{i}, \quad i=0,1, \ldots, n \quad$ mempunyai penyelesaian tunggal untuk $a_{j}$ yang tidak diketahui.

Sedangkan untuk menunjukkan bahwa suatu himpunan fungsi dengan anggota fungsi merupakan kombinasi linier dari fungsi-fungsi yang saling independen merupakan sistem Tchebysheff dengan menggunakan lemma berikut:

Lemma 2.2. [Widiharih (2016)]

Jika $\left\{f_{0}, f_{1}, \ldots f_{n-1}, v_{i}\right\}_{i=1}^{k}$ dengan $v_{i}$ merupakan fungsi-fungsi kontinu dan saling independen, merupakan $k$ buah barisan sistem Tchebysheff, maka $\left\{f_{0}, f_{1}, \ldots f_{n-1}, \sum_{i=1}^{k} v_{i}\right\}$ juga merupakan sistem Tchebysheff.

Dengan menggunakan kosep sistem Tchebysheff dan Teorema 1 bagian 3 dari Li and Majumdar (2008) dapat diputuskan apakah rancangan minimal (minimally supported design) dapat digunakan. Teorema 1 bagian 3 dari Li and Majumdar (2008) seperti pada Teorema 2.2 berkut:

Teorema 2.2 [Li and Majumdar (2008)]

Untuk daerah rancangan $\chi=[a, b]$, jika $\forall \xi \in H, \exists \varepsilon>0$ sehingga setiap fungsi $\{d(x, \xi)-k+c$ : $0<c<\varepsilon\}$ mempunyai paling banyak $2 k-1$ akar pada daerah rancangan $\chi$ maka rancangan D-optimal tersebut merupakan rancangan minimal dan tunggal dan salah satu dari a atau $b$ merupakan titik rancangan. Jika $\forall \xi \in H, \exists \varepsilon>0$ sehingga setiap fungsi $\{d(x, \xi)-k+c: 0<$ $c<\varepsilon\}$ mempunyai paling banyak $2 k-2$ akar pada ruang rancangan $\chi$ maka $a$ dan $b$ merupakan titik rancangan dari rancangan D-optimal. 


\section{HASIL DAN PEMBAHASAN}

\subsection{Rancangan D-optimal Model Gompertz}

Model Gompertz yang digunakan mempunyai bentuk:

$$
\begin{aligned}
& y=\theta_{3} \exp \left(-e^{-\theta_{1} x+\theta_{2}}\right)+\varepsilon, x \in[0, b] \\
& \boldsymbol{\theta}=\left(\theta_{1}, \theta_{2}, \theta_{3}\right) \text { merupakan parameter dari model. } \\
& \boldsymbol{h}(\boldsymbol{x})=\left(\frac{\partial \boldsymbol{\eta}(\boldsymbol{x}, \boldsymbol{\theta})}{\partial \theta_{1}}, \frac{\partial \boldsymbol{\eta}(\boldsymbol{x}, \boldsymbol{\theta})}{\partial \theta_{2}}, \ldots, \frac{\partial \boldsymbol{\eta}(\boldsymbol{x}, \boldsymbol{\theta})}{\partial \theta_{k}}\right)^{T} \\
& \boldsymbol{\eta}(\boldsymbol{x}, \boldsymbol{\theta})=\theta_{3} \exp \left(-e^{-\theta_{1} x+\theta_{2}}\right) \\
& \frac{\partial \boldsymbol{\eta}(\boldsymbol{x}, \boldsymbol{\theta})}{\partial \theta_{1}}=\theta_{3} x e^{-\theta_{1} x+\theta_{2}} \exp \left(-e^{-\theta_{1} x+\theta_{2}}\right) \\
& \frac{\partial \boldsymbol{\eta}(\boldsymbol{x}, \boldsymbol{\theta})}{\partial \theta_{2}}=-\theta_{3} e^{-\theta_{1} x+\theta_{2}} \exp \left(-e^{-\theta_{1} x+\theta_{2}}\right) \\
& \frac{\partial \boldsymbol{\eta}(\boldsymbol{x}, \boldsymbol{\theta})}{\partial \theta_{3}}=\exp \left(-e^{-\theta_{1} x+\theta_{2}}\right)
\end{aligned}
$$

Dengan menggunakan rancangan seperti Persamaan (4) dan $\boldsymbol{h}(\boldsymbol{x})$, elemen matriks informasi $\boldsymbol{M}(\xi, \boldsymbol{\theta})$ adalah:

$$
\begin{aligned}
& m_{11}=\theta_{3}^{2} \sum_{i=1}^{p} w_{i} x_{i}^{2} e^{-2\left(\theta_{1} x_{i}-\theta_{2}\right)} \exp \left(-2 e^{-\theta_{1} x_{i}+\theta_{2}}\right) \\
& m_{22}=\theta_{3}^{2} \sum_{i=1}^{p} w_{i} e^{-2\left(\theta_{1} x_{i}-\theta_{2}\right)} \exp \left(-2 e^{-\theta_{1} x_{i}+\theta_{2}}\right) \\
& m_{12}=-\theta_{3}^{2} \sum_{i=1}^{p} w_{i} x_{i} e^{-2\left(\theta_{1} x_{i}-\theta_{2}\right)} \exp \left(-2 e^{-\theta_{1} x_{i}+\theta_{2}}\right) \\
& m_{33}=\sum_{i=1}^{p} w_{i} \exp \left(-2 e^{-\theta_{1} x_{i}+\theta_{2}}\right) \\
& m_{13}=\theta_{3} \sum_{i=1}^{p} w_{i} x_{i} e^{-\left(\theta_{1} x_{i}-\theta_{2}\right)} \exp \left(-2 e^{-\theta_{1} x_{i}+\theta_{2}}\right) \\
& m_{23}=-\theta_{3} \sum_{i=1}^{p} w_{i} e^{-\left(\theta_{1} x_{i}-\theta_{2}\right)} \exp \left(-2 e^{-\theta_{1} x_{i}+\theta_{2}}\right)
\end{aligned}
$$

Untuk menentukan rancangan D-optimal Model (2) digunakan teorema berikut:

Teorema 3.1

Titik-titik rancangan D-optimal Model (2) adalah $x_{1}, x_{2}$ dan $x_{3}=b, x_{1}, x_{2}$ merupakan titik yang memaksimumkan :

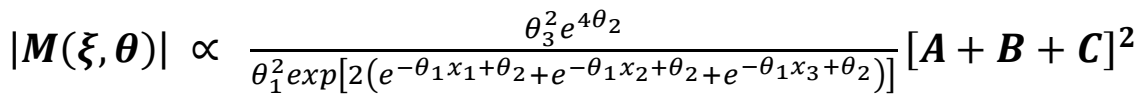

$$
\begin{aligned}
& \text { dengan: } \boldsymbol{A}=e^{-\theta_{1}\left(x_{1}+x_{2}\right)}\left(x_{2}-x_{1}\right) \\
& \boldsymbol{B}=e^{-\theta_{1}\left(x_{2}+x_{3}\right)}\left(x_{3}-x_{2}\right) \\
& \boldsymbol{C}=e^{-\theta_{1}\left(x_{3}+x_{1}\right)}\left(x_{1}-x_{3}\right) \text { dan } x_{3}=b
\end{aligned}
$$

\section{Bukti}

Dinotasikan : $\mathrm{m}^{\mathrm{ij}}$ merupakan elemen baris ke i kolom ke $\mathrm{j}$ dari invers matriks informasi $\mathrm{M}(\xi, \theta)$.

$$
\begin{aligned}
\mathrm{d}(x, \boldsymbol{\xi})= & \boldsymbol{h}^{\boldsymbol{T}}(\boldsymbol{x}) \boldsymbol{M}^{-\mathbf{1}}(\boldsymbol{\xi}) \boldsymbol{h}(\boldsymbol{x}) \\
& m^{11} \theta_{3}^{2} x^{2} e^{-2\left(\theta_{1} x-\theta_{2}\right)} \exp \left(-2 e^{-\theta_{1} x+\theta_{2}}\right)+
\end{aligned}
$$




$$
\begin{aligned}
& m^{22} \theta_{3}^{2} e^{-2\left(\theta_{1} x-\theta_{2}\right)} \exp \left(-2 e^{-\theta_{1} x+\theta_{2}}\right)+ \\
& m^{33} \exp \left(-2 e^{-\theta_{1} x+\theta_{2}}\right)-2 m^{12} \theta_{3}^{2} x e^{-2\left(\theta_{1} x-\theta_{2}\right)} \exp \left(-2 e^{-\theta_{1} x+\theta_{2}}\right)+ \\
& 2 m^{13} \theta_{3} x e^{-\left(\theta_{1} x-\theta_{2}\right)} \exp \left(-2 e^{-\theta_{1} x+\theta_{2}}\right)- \\
& 2 m^{23} \theta_{3} e^{-\left(\theta_{1} x-\theta_{2}\right)} \exp \left(-2 e^{-\theta_{1} x+\theta_{2}}\right) \\
& =\exp \left(-2 e^{-\theta_{1} x+\theta_{2}}\right)\left\{m^{11} \theta_{3}^{2} x^{2} e^{-2\left(\theta_{1} x-\theta_{2}\right)}+m^{22} \theta_{3}^{2} e^{-2\left(\theta_{1} x-\theta_{2}\right)}+\right. \\
& \left.m^{33}-2 m^{12} \theta_{3}^{2} x e^{-2\left(\theta_{1} x-\theta_{2}\right)}+2 m^{13} \theta_{3} x e^{-\left(\theta_{1} x-\theta_{2}\right)}-2 m^{23} \theta_{3} e^{-\left(\theta_{1} x-\theta_{2}\right)}\right\}
\end{aligned}
$$

$\left\{1, e^{-\left(\theta_{1} x-\theta_{2}\right)}, x e^{-\left(\theta_{1} x-\theta_{2}\right)}, e^{-2\left(\theta_{1} x-\theta_{2}\right)}, x e^{-2\left(\theta_{1} x-\theta_{2}\right)}, x^{2} e^{-2\left(\theta_{1} x-\theta_{2}\right)}\right\}$ merupakan sistem Tchebysheff, dan $\mathrm{d}(x, \xi)$ merupakan kombinasi linear dari $\left\{1, e^{-\left(\theta_{1} x-\theta_{2}\right)}, x e^{-\left(\theta_{1} x-\theta_{2}\right)}, e^{-2\left(\theta_{1} x-\theta_{2}\right)}, x e^{-2\left(\theta_{1} x-\theta_{2}\right)}, x^{2} e^{-2\left(\theta_{1} x-\theta_{2}\right)}\right\}$. Sehingga sehingga setiap fungsi $\{\mathrm{d}(x, \xi)-3+\mathrm{c}: 0<c<\varepsilon\}$ mempunyai paling banyak $2 k-1=5$ akar, dengan $k=3$ (banyaknya parameter dalam model). Mengacu pada Teorema 1 maka rancangan yang digunakan merupakan rancangan minimal dengan $b$ merupakan titik rancangan. Diperoleh rancangan:

$$
\xi=\left(\begin{array}{ccc}
x_{1} & x_{2} & b \\
\frac{1}{3} & \frac{1}{3} & \frac{1}{3}
\end{array}\right)
$$

Berdasarkan titik-titik rancangan seperti pada Persamaan (10), elemen matriks informasi $\boldsymbol{M}(\xi, \boldsymbol{\theta})$ adalah:

$$
\begin{aligned}
& m_{11}=\frac{1}{3} \theta_{3}^{2} \sum_{i=1}^{3} x_{i}^{2} e^{-2\left(\theta_{1} x_{i}-\theta_{2}\right)} \exp \left(-2 e^{-\theta_{1} x_{i}+\theta_{2}}\right) \\
& m_{22}=\frac{1}{3} \theta_{3}^{2} \sum_{i=1}^{3} e^{-2\left(\theta_{1} x_{i}-\theta_{2}\right)} \exp \left(-2 e^{-\theta_{1} x_{i}+\theta_{2}}\right) \\
& m_{12}=-\frac{1}{3} \theta_{3}^{2} \sum_{i=1}^{3} x_{i} e^{-2\left(\theta_{1} x_{i}-\theta_{2}\right)} \exp \left(-2 e^{-\theta_{1} x_{i}+\theta_{2}}\right) \\
& m_{33}=\frac{1}{3} \sum_{i=1}^{3} \exp \left(-2 e^{-\theta_{1} x_{i}+\theta_{2}}\right) \\
& m_{13}=\frac{1}{3} \theta_{3} \sum_{i=1}^{3} x_{i} e^{-\left(\theta_{1} x_{i}-\theta_{2}\right)} \exp \left(-2 e^{-\theta_{1} x_{i}+\theta_{2}}\right) \\
& m_{23}=-\theta_{3} \sum_{i=1}^{3} e^{-\left(\theta_{1} x_{i}-\theta_{2}\right)} \exp \left(-2 e^{-\theta_{1} x_{i}+\theta_{2}}\right)
\end{aligned}
$$

Sehingga diperoleh:

$$
|\boldsymbol{M}(\boldsymbol{\xi}, \boldsymbol{\theta})| \propto \frac{\theta_{3}^{2} e^{4 \theta_{2}}}{\theta_{1}^{2} \exp \left[2\left(e^{-\theta_{1} x_{1}+\theta_{2}}+e^{-\theta_{1} x_{2}+\theta_{2}}+e^{-\theta_{1} x_{3}+\theta_{2}}\right)\right]}[\boldsymbol{A}+\boldsymbol{B}+\boldsymbol{C}]^{2}
$$

dengan: $\boldsymbol{A}=e^{-\theta_{1}\left(x_{1}+x_{2}\right)}\left(x_{2}-x_{1}\right)$

$$
\begin{aligned}
& \boldsymbol{B}=e^{-\theta_{1}\left(x_{2}+x_{3}\right)}\left(x_{3}-x_{2}\right) \\
& \boldsymbol{C}=e^{-\theta_{1}\left(x_{3}+x_{1}\right)}\left(x_{1}-x_{3}\right) \text { dan } x_{3}=b
\end{aligned}
$$

Berdasarkan Teorema 3.1 yang diperoleh terlihat bahwa rancangan D-optimal model Gompertz merupakan rancangan minimal dengan batas atas daerah rancangan merupakan salah satu titik rancangan. 


\subsection{Program Maple Untuk Penentuan Titik-titik Rancangan D-optimal}

Titik-titik $x_{1}, x_{2}$ merupakan titik-titik yang memaksimumkan $|\boldsymbol{M}(\xi, \boldsymbol{\theta})|$ seperti pada Persamaan (9), merupakan bentuk nonlinear yang sangat rumit. Metode optimasi yang digunakan adalah Modifikasi Newton (modified Newton). Penentuan titik-titik rancangan D-optimal ini menggunakan program Maple 12 sebagai berikut:

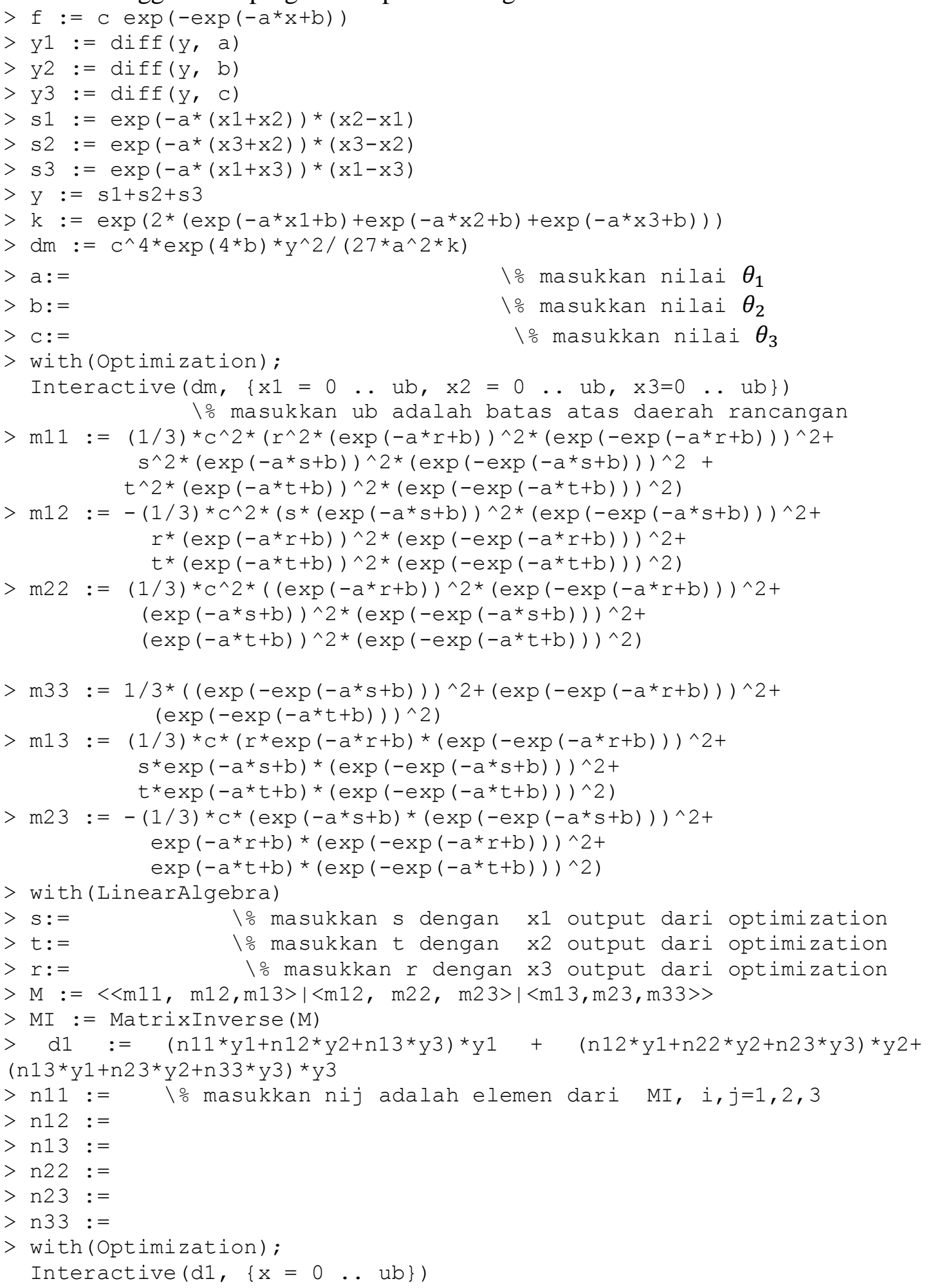

Hasil simulasi dari program untuk beberapa nilai $\theta_{1}, \theta_{2}$, dan $\theta_{3}=0,3$ dengan daerah rancangan $[0,25]$ seperti pada Tabel 1 . 
Tabel 1 Titik-titik Rancangan D-optimal Model (2) Pada Beberapa Nilai $\theta_{1}, \theta_{2}$, dan $\theta_{3}=$ 0.3 dengan daerah rancangan $[0,25]$

\begin{tabular}{ccccc}
\hline$\theta_{1}$ & $\theta_{2}$ & $x_{1}$ & $x_{2}$ & $x_{3}$ \\
\hline 0,1 & 0,2 & 0,000 & 10,4795 & 25 \\
0,2 & 0,2 & 0,000 & 6,8072 & 25 \\
0,3 & 0,2 & 0,000 & 4,7073 & 25 \\
0,4 & 0,2 & 0,000 & 3,5463 & 25 \\
0,5 & 0,2 & 0,000 & 2,8385 & 25 \\
0,5 & 0,1 & 0,000 & 2,7665 & 25 \\
0,5 & 0,3 & 0,000 & 2,9158 & 25 \\
0,5 & 1,0 & 1,000 & 4,0874 & 25 \\
0,5 & 1,5 & 2,000 & 5,0872 & 25 \\
0,5 & 2,0 & 3,000 & 6,0869 & 25 \\
\hline
\end{tabular}

Setiap pasangan titik yang bersesuaian dengan nilai $\theta_{1}, \theta_{2}$ pada Tabel 1 tersebut memenuhi Teorema Tergeneralisasi Kiefer Wolvofitz (1960), yaitu: $\mathrm{d}(x, \xi)=\boldsymbol{h}^{\boldsymbol{T}}(\boldsymbol{x}) \boldsymbol{M}^{-1}(\xi) \boldsymbol{h}(\boldsymbol{x}) \leq 3$. Sebagai ilustrasi untuk $\theta_{1}=0,1 \quad \theta_{2}=0,2$, diperoleh rancangan:

$$
\xi=\left(\begin{array}{ccc}
0 & 10,4795 & 25 \\
\frac{1}{3} & \frac{1}{3} & \frac{1}{3}
\end{array}\right)
$$

Matriks Informasi yang bersesuaian degan rancangan (11) adalah:

$$
M(\xi)=\left(\begin{array}{ccc}
0,41084 & -0,03066 & 0,39568 \\
-0,03066 & 0,00647 & -0,03701 \\
0,39568 & -0,03701 & 0,44328
\end{array}\right)
$$

Invers dari matriks informasi (12) adalah:

$$
M^{-1}(\xi)=\left(\begin{array}{ccc}
17,86707 & -12,54918 & -16,99634 \\
-12,54918 & 304,32454 & 36,60756 \\
-16,99634 & 36,60756 & 20,48347
\end{array}\right)
$$

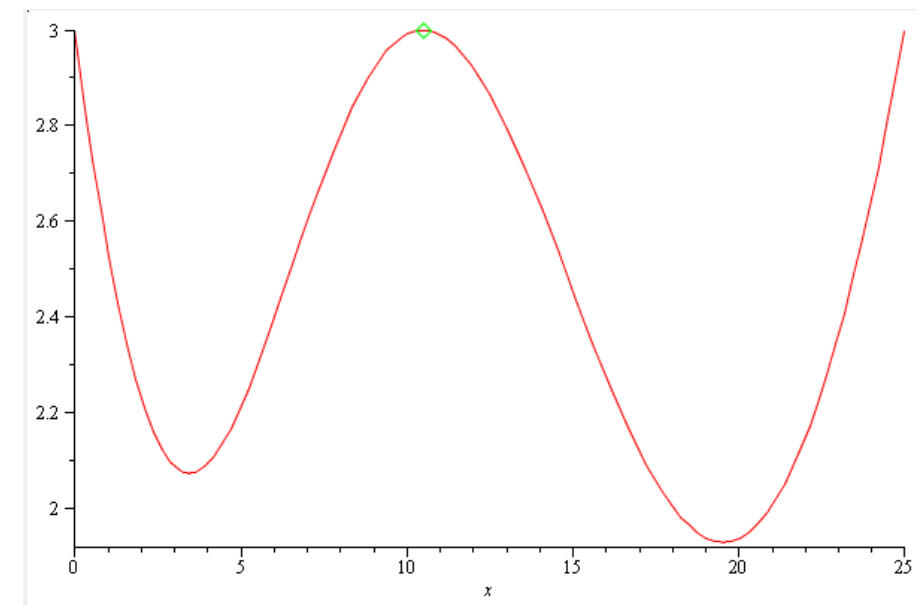

Gambar 2. Grafik Variansi Terstandar Model (2) dengan Rancangan Persamaan (11) 
Variansi terstandar pada titik-titik Rancangan (11) ketiganya adalah 2,99999 (diperoleh dari output program baris terakhir), sehingga memenuhi Teorema Tergeneralisasi Kiefer Wolvofitz (1960), yaitu: $\mathrm{d}(x, \xi)=\boldsymbol{h}^{\boldsymbol{T}}(\boldsymbol{x}) \boldsymbol{M}^{-\mathbf{1}}(\boldsymbol{\xi}) \boldsymbol{h}(\boldsymbol{x}) \leq 3$. Hal ini dapat ditunjukkan pada Gambar 2, dimana sumbu mendatar adalah daerah rancangan dan sumbu tegak nilai variansi terstandar.

\section{KESIMPULAN}

Penentuan titik-titik rancangan D-optimal tergantung dari informasi awal tentang nilai dari paramater dalam model. Optimasi dari fungsi determinan matriks informasi dilakukan secara numeris dengan metode Newton Termodifikasi. Hasil yang diperoleh berupa Teorema 3.1, rancangan D-optimal model Gompertz merupakan rancangan minimal dengan batas atas daerah rancangan merupakan salah satu titik rancangan, proporsi masingmasing titik rancangan $\frac{1}{3}$. Diperlukan penelitian lebih lanjut tentang rancangan D-optimal model Gompertz ini pada kasus error bersifat heterokedastik.

\section{DAFTAR PUSTAKA}

Atkinson, A.C., Donev, A.N., and Tobias,R.D., 2007. Optimum Experimental Designs, with SAS, OXFORD University Press.

Antille, G .,Dette,H.,and Weinberg, A., 2003. A Note On Optimal Designs In Weighted Polynomial Regression For The Classical Efficiency Functions, Journal of Statistical Planning and Inference, Vol.113, pp 285-292.

Boon, J.E., 2007, Generating Exact D-optimal Designs for Polynomial Models, Spring Sim, Vol.2 , pp 121-126

Chang, F.C., and Lay, C.F., 2002. Optimal Designs for a Growth Curve Models, Journal of Statistical Planning and Inference, Vol.104, pp 427-438.

Chernoff, H., 1953. Locally Optimal Designs for Estimating Parameters, The Annals of Statistics, Vol.24, pp 586 - 602.

Dette, H., Melas, V.B. and Wong, W.K., 2006. Locally D-optimal Designs for Exponential Regression Models, Statistica Sinica, Vol.16, pp 789-803.

Dette, H and Pepelyshev, A., 2008. Efficient Experimental Designs for Sigmoidal Growth Models, Journal of Statistical Planning and Inference, Vol.138, pp 2-17.

Dette, H and Trampisch M., 2010. A General Approach To D-Optimal Designs For Weighted Univariate Polynomial Regression Models, Journal of The Korean Statistical Society, Vol. 39, pp 1-26.

Fang, Z., 2002. D-optimal designs for polynomial regression model through origin, Statistics and Probability Letters, Vol.57, pp 343-351.

Fang, Z ., 2003. D-optimal designs for weighted polynomial regression, Statistics and Probability Letters, Vol.63, pp 205-213.

Han, C., and Chaloner, K., 2003. D-and c-optimal Designs for Exponential Regression Models Used in Viral Dynamics and other Applications, Journal of Statistical Planning and Inference, Vol.115, pp 585-601. 
Huang Lo, M.N., Chang, F.C., and Wong, W.K., 1995. D-optimal Designs for Polynomial Regression Without an Intercept, Statistica Sinica, Vol. 5, pp 441-458.

Imhof, L.A., 2001, Maximin Designs for Exponential Growth Models and Heteroscedastic Polynomial Models, The Annals of Statistics, Vo. 29, No.2, pp 561-576.

Karlin, S., and Studden, W.J., 1966. Tchebyshev System:With Application in Analysis and Statistics, Wiley, New York ,1966.

Kiefer, J., and Wolfowitz, J., 1959, Optimum Designs in Regression Problems, Annals of Mathematical Statistics, Vol.30, pp 271-294.

Kiefer, J., and Wolfowitz, J., 1960. The Equivalence of Two Extremum Problems, Can. Jnl. Math, Vol. 12, pp 363-366.

Kiefer, J., 1961, Optimum Designs in Regression Problems II, Annals of Mathematical Statistics, Vol.32, pp 298-325.

Kiefer, J.,1974, General Equivalence Theory for Optimum Designs (Approximate Theory), The Annals of Statistics, Vol.2, No.5, pp 849-879

Li, G., and Majumdar, D., 2008. D-optimal designs for logistic models with three and four parameters, Journal of Statistical Planning and Inference, Vol. 138, pp 190-1959.

Li, G., and Balakrishnan, N.,2011. Optimal Designs for Tumor Regrowth Models, Journal of Statistical Planning and Inference, Vol.141, pp 644-654.

Luoma, A., Nummi, T., and Sinha, B.K., 2007. Optimal Designs in Random Coeffisient Cubic Regression Models, Journal of Statistical Planning and Inference, Vol.137, pp 3611-3617.

Shadrin, A., 2005. Part III-Lent Term 2005, Approximation Theory-Lecture 6, A Short Course, http:www.damtp.cam.uk/user/na/na.html.

Wald, A., 1943. On The Efficient Design of Statistical Investigations, Annals of Mathematical Statistics, Vol.14, pp 134-140.

White,L., 1973. An Extension of the general equivalence theorem to nonlinear models, Biometrika, Vol. 60, pp 345-348.

Widiharih, T., 2016. Rancangan D-optimal Untuk Model Eksponensial Tergenerlisasi, Eksponensial Terboboti dan Morgan Mercer Flodin (MMF), (Disertasi Ilmu Matematika UGM, tidak dipublikaskan)

Widiharih, T., Haryatmi,S., dan Gunardi., 2013a. D-optimal Design Untuk Regresi Polinomial Terboboti, IndoMS Journal on Statistics, Vol.1, No.1, pp 29-38

Widiharih, T., Haryatmi,S., and Gunardi., 2013b. D-optimal designs for weighted exponential and generalized exponential models, Applied Mathematical Sciences, Vol.7 No.22, pp 1067-1079

Widiharih,T., Haryatmi,S., dan Gunardi., 2014. Rancangan D-optimal Untuk Model Eksponensial Tergeneral, Media Statistika, Vol.7 No.2, pp 71-76.

Widiharih,T., Haryatmi,S., and Gunardi., 2015. D-optimal designs for Morgan Mercer Flodin (MMF) Models without Intercept, International Journal of Applied Mathematics and Statistics, Vol.53, No.5, pp 163-171. 
Widiharih,T., Haryatmi,S., and Gunardi., 2016a. D-optimal designs for Morgan Mercer Flodin (MMF) Models With Three Parameters, Proceeding AIP, 1707, 080015 , pp 080015_1-080015_10

Widiharih,T., Haryatmi,S., and Gunardi., 2016b. D-optmal Designs for Modified Exponential Models With Three Parameters, Journal Model Assisted Statistics and Application, Vol.11, pp 153-169. 